\title{
Contributive factors for the consolidation of patient safety culture in the hospital environment
}

Fatores contribuintes para consolidação da cultura de segurança do paciente no âmbito hospitalar Factores que contribuyen a consolidar la cultura de seguridad del paciente en el ámbito hospitalario

Andréia Heidmann ${ }^{1}(1)$ Letícia Flores Trindade ${ }^{1}(\mathbb{C})$ Catiele Raquel Schmidt ${ }^{1}$ (i)

Marli Maria Loro ${ }^{1}$

Rosane Teresinha Fontana ${ }^{2}$ (16)

Adriane Cristina Bernat Kolankiewicz ${ }^{1}$ (1)

${ }^{1}$ Universidade Regional do Noroeste do Estado do Rio Grande do Sul, Rio Grande do Sul, RS, Brasil. ${ }^{2}$ Universidade Regional Integrada do Alto Uruguai e das Missões, Santo Ângelo, RS, Brasil.
Corresponding author:

Adriane Cristina Bernat Kolankiewicz

E-mail:adri.saudecoletiva@gmail.com

Submitted on 05/22/2019.

Accepted on $08 / 27 / 2019$.

DOI: 10.1590/2177-9465-EAN-2019-0153

\begin{abstract}
Objective: To understand the contributing factors for the consolidation of the patient safety culture, from a management perspective, in an accredited hospital. Method: A qualitative study developed in a hospital institution of size IV, accredited by the National Accreditation Organization as level II, located in the northwest region of the State of Rio Grande do Sul/Brazil. The inclusion criteria were the following: having been in the leadership position of the institution for over a year and actively participating in the accreditation process. Leaders on vacation or absent due to illness in August 2018 were excluded. The collection was performed using the Focus Group technique in August 2018. Data were explored by thematic analysis. Results: The group reported teamwork, professional appreciation, management support, implementation of protocols, professional satisfaction, and working conditions as factors that contributed to the consolidation of the safety culture. Conclusions and implications for practice: The identified factors allowed for a cultural change in the institution through participatory management in processes and results that encourage workers to assume significant roles in advancing patient safety by assimilating and taking responsibility for change, which plays a crucial role in developing safe care.
\end{abstract}

Keywords: Patient safety; Leadership; Health Services Administration; Focus Group; Multi-professional team.

\section{Resumo}

Objetivo: Compreender os fatores contribuintes para a consolidação da cultura de segurança do paciente, na perspectiva de lideranças, em um hospital acreditado. Método: Estudo qualitativo, desenvolvido em uma instituição hospitalar de porte IV, acreditada pela Organização Nacional de Acreditação nível II, situado na região noroeste do Estado do Rio Grande do Sul/Brasil. Constituíram-se em inclusão: atuar em cargo de liderança na instituição há mais de um ano e ter participado ativamente no processo de acreditação. Excluídas lideranças em período de férias ou licença saúde. A coleta foi realizada por meio de técnica de Grupo Focal, em agosto de 2018. Análise dos dados foi por análise temática. Resultados: O grupo relatou o trabalho em equipe, a valorização profissional, o apoio da gerência, a implantação de protocolos, a satisfação profissional e as condições de trabalho como fatores que contribuíram na consolidação da cultura segura. Conclusões e implicações para a prática: Os fatores identificados permitiram a mudança cultural na instituição, por meio de uma gestão participativa nos processos e resultados, que encorajam os trabalhadores a assumir papéis significativos no avanço da segurança do paciente, assimilando e assumindo a responsabilidade pelas mudanças, que foram fundamentais para desenvolver uma assistência segura.

Palavras-chave: Segurança do paciente; Lideranças; Administração de serviços de saúde; Grupo focal; Equipe multiprofissional.

\section{Resumen}

Objetivo: Comprender los factores que contribuyen a la consolidación de la cultura de seguridad del paciente, desde la perspectiva de los líderes, en un hospital acreditado. Método: Estudio cualitativo, desarrollado en una institución hospitalaria de tamaño IV, acreditado por la Organización Nacional de Acreditación de nivel II, ubicado en la región noroeste del estado de Rio Grande do Sul/Brasil. En la inclusión de la investigación se tuvo en cuenta: actuar en posición de liderazgo en la institución por más de un año y participar activamente en el proceso de acreditación. Se excluyeron los líderes en vacaciones o en licencia por enfermedad. La recolección de datos se realizó utilizando la técnica del grupo de enfoque en agosto de 2018. El análisis de datos se realizó mediante análisis temático. Resultados: El grupo informó que el trabajo en equipo, el reconocimiento profesional, el apoyo administrativo, la implementación del protocolo, la satisfacción laboral y las condiciones laborales son factores que contribuyeron a consolidar una cultura segura. Conclusiones e implicaciones para la práctica: Los factores identificados han permitido un cambio cultural en la institución, a través de la gestión participativa de los procesos y resultados, que alientan a los trabajadores a asumir roles significativos en el avance de la seguridad del paciente al asimilar y asumir la responsabilidad del cambio, que fueron fundamentales para desarrollar una atención segura.

Palabras clave: Seguridad del paciente; Liderazgo; Administración de los Servicios de Salud; Grupo Focal; Equipo multiprofesional. 


\section{INTRODUCTION}

Patient Safety (PS) is a topic discussed worldwide and is essential for improving the quality of health services. Discussions on the topic started with the publication of the report "To Err is human: building a safer health system". ${ }^{1}$

Important initiatives have been taken since then, such as the creation of the World Alliance for Patient Safety, now called the Patient Safety Program ${ }^{2}$ the elaboration of Global Challenges for PS by the World Health Organization (WHO), ${ }^{3}$ the creation of strengthening networks such as the International Nursing and Patient Safety Network (Rede Internacional de Enfermagem e Segurança do Paciente, RIENSP) in $2005^{4}$ and the Brazilian Network of Nursing and Patient Safety (Rede Brasileira de Enfermagem e Segurança do Paciente, REBRAENSP) created in $2008 ;{ }^{5}$ common among the initiatives is the goal of reducing health care-related adverse events (AEs) and providing safe care.

In Brazil, the framework of the discussions took place in 2013, with the launch of the National Patient Safety Program (Programa Nacional de Segurança do Paciente, PNSP), published through Ordinance No. 529, which has to oversee and monitor AEs in health care as one of the strategies. ${ }^{6}$ Also in the same year, Collegiate Board Resolution (Resolução da Diretoria Colegiada, RDC) No. 36 was published, which establishes actions for PS and defines safety culture as a set of values, attitudes and behaviors that determine commitment to health and safety management, replacing the punishment for the opportunity to learn from failures and improve health care ${ }^{7}$. It is thus understood that a punitive culture does not encourage prevention and has negative consequences such as concealment of errors. In this sense, it is necessary to evaluate and make a fair culture viable, characterized by greater transparency in health care. ${ }^{8}$

Thus, assessing safety culture is important to measure the organizational conditions that lead to potential health care-related AEs, ${ }^{9}$ as these events are underreported in Brazil. ${ }^{10}$ Also, institutions that seek to improve quality of care should use evidence to guide actions to promote cultural change.

In this sense, the use of clearly defined methods that elucidate the positive experiences in institutions, signal for possible interventions that boost the quality of care and PS. ${ }^{11}$ From this context, this study has as the following guiding question: What factors contribute to a positive patient safety culture in a hospital institution? Thus, the objective of the study was to understand contributing factors for the consolidation of the patient safety culture, from the perspective of leaders, in an accredited hospital.

\section{METHOD}

Study linked to the matrix project: "Safety culture assessment from the perspective of a hospital institution", developed in a hospital of size IV, accredited by the National Accreditation Organization (Organização Nacional de Acreditação, ONA) as level II, in the northwest region of the state of Rio Grande do Sul/Brazil.
Developed in two phases: quantitative assessment of the PS culture, carried out in 2017 , by a safety climate assessment with the participation of the multi-professional and support team, through the Safety Attitudes Questionnaire (SAQ) instrument, validated for Brazil. ${ }^{12}$ The instrument assesses perceptions of professionals regarding PS and covers six domains: safety climate, team work environment, job satisfaction, perception of the unit and hospital management, working conditions and stress recognition. ${ }^{12}$

After analyzing the results of the quantitative phase, the second phase of the research presented in the study was carried out. This is a qualitative, descriptive study that uses the focus group (FG) with leaders of the investigated institution as data collection technique, in order to understand the factors that contributed to the consolidation of the culture of PS.

Participants in the second phase were initially identified by the project coordinator, with the help of the hospital's human resources department, which provided the organization chart for the nursing service, as well as other professional categories. Based on this information, the possible participants of the FG were elected.

The study included leaders for more than a year and who actively participated in the accreditation process. The study participants were representatives who worked directly and permanently with the multi-professional team, apart from with support areas. They were invited by the project coordinator to join the study. Leaders on vacation or absent due to illness in the month of August, 2018 were excluded.

The FG was composed by a moderator, project coordinator and two observers, who were responsible for the non-verbal records. It was held in August 2018 in the hospital and in a reserved place, by prior appointment, which ensured a comfortable environment and privacy for the participants. Still, the 12 participants were placed in a circle around a table, which favored vision among all.

The FG was held in two moments, with a duration of 90 minutes for each meeting, and an interval of 15 minutes. Initially the research team, together with the hospital management, welcomed the participants to support the FG, making themselves available. Still, water, coffee and snacks were available, which could be freely consumed during the discussions. The strategy used aimed at comfort and disposition for the activities.

At the set time, the activities began with the presentation of the researcher and the observers in the group, as well as the study participants. Sequentially, the researcher explained the objectives of the study and performed the reading and delivery of the Free and Informed Consent. Then the activity began with an integrative dynamics. At this moment, the participants received a jigsaw puzzle, which instigated the reflection of teamwork, being fundamental for the development of the activity. 
They were identified with the letter $P$, followed by a numerical sequence, i.e., $\mathrm{P} 1$ to $\mathrm{P} 12$, in order to preserve the anonymity of the individuals. The FG sessions were recorded in audio type, and the information contained therein was fully transcribed.

Data was analyzed using the thematic content analysis technique, according to the following phases: pre-analysis, material exploration, treatment, inference and interpretation of the results obtained. ${ }^{13}$ The study was approved by the Research Ethics Committee under substantiated opinion No. 1,935,252 of 2/21/2017.

\section{RESULTS}

Nine coordinating, assisting and managerial nurses, one nutritionist, one billing manager and one pharmacist participated. Initially, the FG coordinator spoke about the safety culture theme in the institution, from previous results that denoted positive culture and reflection about the aspects that contributed to a positive PS culture.

GOradually, members were comfortable expressing their ideas, listening to opinions and building ideas collectively. Subsequently, through divergences and convergences, the FG components reviewed the constructed data and validated the main aspects that drove and enabled the change in the PS culture, in order to identify factors treated as categories of analysis, namely: (Figure 1)

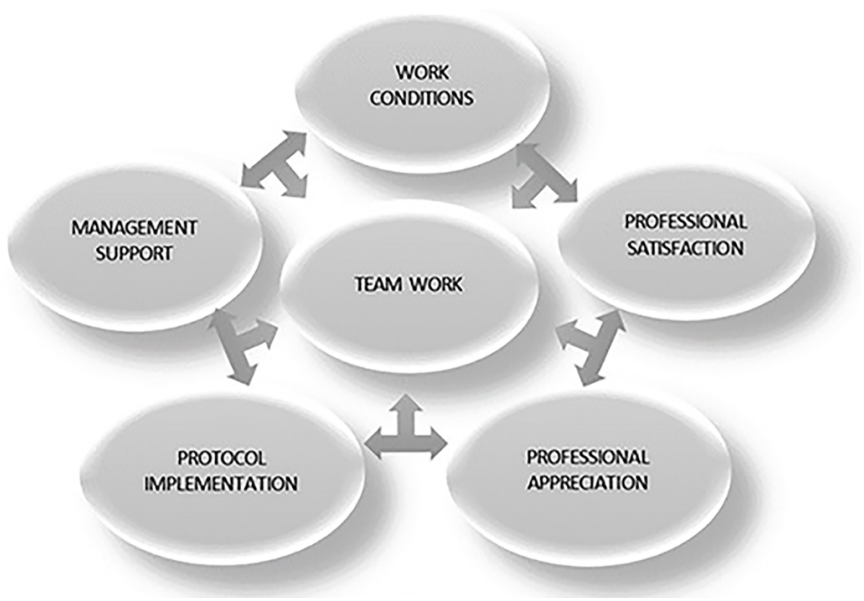

Figure 1. Contributing factors identified by the FG participants.

\section{Team work}

Participants mentioned the teamwork and collaboration of all as aspects that allowed the consolidation of the safety culture.

We work a lot as a team, nothing works in a one-man job, [...] because we need everyone to make a difference (P4, P11).

The feedback from their leaders was also mentioned on the importance of teamwork, dialog, bonding and mutual cooperation in solving problems.
Management stresses the importance of sharing satisfaction survey results with their teams and showing everyone's importance in the outcome (P6).

So much is team work, that in this group, everyone has talked at some point, to solve some situation in favor of the PS (P11).

Teamwork is much discussed to solve problems without friction between teams, but bring improvements to the patient (P8).

Changes in culture imply a new vision of multidisciplinary work, challenges have been and still are faced, especially with the medical team.

In recent years we have had changes [...] we need to hear each other. Any change that the nurse makes, e.g. in the operating room, he contacts the billing, the pharmacy, to know how this will reflect in the other area (P12).

We still have difficulty with doctors, but it has improved a lot. Previously, the work should be done according to what the doctor says, today we know that everyone is important in the team, so each one has to do their part. The culture in the institution is changing (P8).

There is concern of the teams with the satisfaction in the service. The commitment of all to do their best and prioritize the patient is evident, even in unfavorable conditions.

[...] even in a six-patient ward, the patient satisfaction survey is $96 \%$. The team arrives willing to attend, they demand of each other when they are with the team, but with the patient we want to do the best (P6).

In the emergency unit, patient satisfaction is not easy, since it requires resoluteness. This sometimes distresses the team, who are always being encouraged and supported to maintain good communication and plan strategies to achieve a high level of satisfaction (P2).

The effort to ensure access to information involves new employees who are integrated into the change process even with some resistance.

The new employee has daily integration, working hard on patient and worker safety, and professionals value the opportunity to work within the institution. We are consolidating a safety culture where the community understands that the hospital seeks improvements for both professionals and patients ( $P 8)$.

As younger employees receive criticism, they sometimes do not accept and want to respond, or listen, but do not accept (P6). 


\section{Professional Appreciation}

In this regard, participants mentioned signal horizontal dialog and multi-professional collaboration as relevant factors in achieving goals.

We talk to professionals horizontally, there is no hierarchy of direction and leadership, each has their responsibilities and everyone is respected, what motivates them and each recognizes their importance in the team (P6).

I have experience of another hospital, which valued the doctor. When I arrived at this hospital 20 years ago, I realized that the culture was different and I was surprised how I was received, with the teamwork and the work process, with the appreciation of the nurse and, over the years, this process was improved (P3).

\section{Management Support}

The changes in the institution brought positive results from the active participation of managers, perceived as essential to perform the work safely and confidently.

It was clear, after the change of direction of the hospital, the love and support that workers receive from the directors and managers, unlike other hospitals (P3).

We who work at night have security, because we are not alone. If need something, I can call, regardless of time, the colleague nurse, nursing coordinator, hospital director, who will assist and support me. This gives more confidence and autonomy for support (P5).

Here we have the hospital management as reference. She follows the work of the professionals, we see her in the corridors at midnight, without obligation, talking with patients and the team, this makes us feel valued, motivated and reflected in the development of the work (P9).

The proximity of managers with the working environment and staff is essential. Even in difficult situations, the group feels supported and committed to encourage non-punitive culture and exposes situations to their coordinators and managers, in order to solve problems together, which emphasizes and strengthens teamwork.

Having management as an ally is a differential, it does not happen everywhere, we realize in other surveys that direction and leadership are far from who is really on the edge (P3).

Even in difficult situations, they have a way of motivating us and showing us how important each one is and that makes a difference. When there is a situation, it is always shared and we see how hard the management strives, so we have security. This motivates us and gives us job satisfaction (P6, P7).

\section{Protocol Implementation}

Deponents point out that the protocols empower nursing, allied to the support they receive from management, which keeps everyone engaged in the pursuit of a common goal.

Protocols support our work, because if you follow them, you know you're right, all professionals will provide assistance in a standardized way (P9).

And the support we have, [...] because the medical class had resistance. No matter who the professional is, there is no need to be afraid, we have help and support, because the PS involves everyone. So, I can talk to the management, if something happened and I'm right, they will support me, the protocol must be followed (P6).

When new doctors come, they try to clash and slowly they get into the mood and change (P1).

Protocols set a standard and all sectors need to talk to each other for organized care, which qualifies institutional work and promotes the PS culture. Participants emphasize the importance of team dialog to assess protocol gaps that may harm work or patient, enabling review and updating to improve barriers to lowering AEs.

When I need a medication, there is a bureaucratic issue and I need to follow the protocols, those in front of the patient are in a more tense situation than the staff in the pharmacy (P6).

The protocol is a barrier, but it requires creativity, because you need to comply with it, but sometimes it needs to be reviewed and modified, because at the time of performing the sequence you realize the gaps and this generates stress (P6).

\section{Job satisfaction}

It was listed as an aspect that contributes to the consolidation of the safety culture, expressed in the report of the opportunity that the institution offers to the workers.

I was a nursing technician and today I am a nurse, we have encouragement from the management, who has openness and easy access (P3).

Satisfaction is also cited in relation to rates of pay, be paid on time, which affects both health institutions, in contemporary times.

Compensation counts because just looking around us, the salary, it also generates satisfaction. It depends on how your salary is, you see newspapernews, turn on the $T V$, it's paid over delay. We have no delay (P6, P7, P9).

\section{Work conditions}

The stress and the effort to achieve accreditation are rewarded by the appropriate work environment and team awareness. 
When I started working here, even though the hospital was scrapped, we had to stimulate the team (P7).

Stress has increased with demands for accreditation, but working conditions have improved. We accomplished a lot together (P11).

The certification of the institution is seen by the workers, as a stimulus for the continuity of efforts by PS, even with requests and demands, the team says it is satisfied.

Today employees are satisfied with certification, even if there is stress, request, demand, they are satisfied. We have the recognition of the work (P7).

As a final reflection, they were invited to assemble a puzzle, which contained the following sentence: "Alone we win sometimes, but as a team we can win constantly". The strategy aimed to synthesize the centrality of collective construction, which required participants to work together to obtain the final result.

\section{DISCUSSION}

Teamwork becomes critical to an effective safety culture. The involvement of workers from various sectors and levels promotes integration and contribution to the institution, which allows the joining of efforts, the emergence of ideas and the performance of activities with high performance. ${ }^{14}$

Conflict resolution between teams indicates a level of maturity that goes beyond individual goals in favor of improvements to consolidate PS. The need for change and pf overcoming current models of care and supervision, towards a work built collectively, aims to cooperate and stimulate the team in order to better patient care. ${ }^{15}$

Mutual cooperation between teams results in greater bonding and in a consequent improvement in communication skills, which facilitates problem solving. Communication as an instrument of care, is an element in the set of actions which contributes to PS, mainly, to transmit messages completely, without barriers or noise, among team members. ${ }^{16}$

The interaction between the teams, in transmitting or hearing the message, was fundamental in the hospital accreditation process, because changes in the institution required clear communication between the sectors to enable the operationalization of care. As health professionals improve this idea of collective responsibility, it is possible to advance towards the consolidation of the PS culture. ${ }^{14}$

Cultural consolidation required a collective effort, including the medical profession, which presented some resistance, which was also evidenced in a study in an institution in Piracicaba, São Paulo. ${ }^{17}$
Authors attribute this resistance to the current educational model, which needs to be rethought, to enable the incorporation of the theme throughout academic education, in order to change the current landscape and reduce health practices that accumulate risks and potentialize failures. ${ }^{14} \mathrm{~A}$ study in Germany found that the implementation of inter-professional continuing education in health policy and care practice, which encourages teamwork, notes the rare participation of doctors and seeks ways to bring all professionals into action, even with the possibility of making participation mandatory, to promote PS. ${ }^{18}$

The changes that took place in the institution to develop the safety culture demanded a lot from the teams. The collective effort to achieve positive levels of service satisfaction came with a lot of work. The ability of adaptation and overcoming are more demanded of nursing workers when immersed in a stressful daily work. May present professional burnout as the body's response to this stress routine. ${ }^{19}$ Even in situations that demand more psychological and mental state, the team was satisfied, stimulated and supported to continue the work.

New workers in the institution face difficulties when they encounter activities that require efforts and commitment to establish a safe culture. The workload of training for integration in the process and clarification about cultural change generates resistance and criticism from those workers who, after understanding the main goal, value the opportunity to be part of an institution that is already recognized for prioritizing integrated management by outlining action plans for improvements that ensure safe care. The involvement of all professionals in the care process is necessary for changes to occur, as they face the need to update not only theoretical but practical, to provide effectiveness of processes, ensuring PS. ${ }^{20}$

Teamwork is a daily construction driven by incentive, which requires interaction, communication and empathy, respecting the diversity of knowledge in each specificity. Therefore, it is indispensable for PS because it has a direct influence on the quality of care. Participants highlighted that the involvement of all professionals, feedback from the collective effort, dialog, bonding and mutual cooperation reinforce the team relationship.

Participants listed professional appreciation as essential. Professionals feel valued for the space and freedom they have to expose their wishes and contributions. The moments of discussion and learning that involve managers and professionals with the care process guarantee reflection on PS. ${ }^{21}$

The dialogs between the teams are horizontal, as the objectives are common, and all assume their responsibilities, without 
distinction to address shared issues. Nursing plays an important role in expanding the knowledge of PS among the other team members, since it develops this skill since its formation to lead the strategic management actions ${ }^{22}$ in a collective way, between health teams, with the purpose of cooperation and encouragement to the worker, to achieve the improvement of patient care..$^{20}$

Professional appreciation promotes the autonomy necessary to perform the proposed tasks, to implement change. The appreciation of people is fundamental, as they are agents that drive the entire process that triggers the production of quality service.$^{23}$ In a work team, valuing people makes a difference as they become more motivated to perform their tasks ${ }^{24}$ and provides support for the development and consolidation of institutional policies. ${ }^{25}$

The leaders attributed the positive results achieved by the institution, due to the support they receive from hospital managers. Participatory management promotes team autonomy in problem solving, the support to workers is felt and experienced in a welcoming manner, they feel supported to perform their duties. The well-being of professionals provides better results in the workplace. If health care professionals are sufficiently supported in their efforts, they will have greater joy at work and provide safe and efficient care. ${ }^{26}$

Safe care is permeated by the construction of the model that the institution set out to seek, in order to strengthen the culture of PS, managers should pay attention to a participatory management model, with horizontal structures that meet the needs of patients and professionals. ${ }^{25}$ Building a safety culture through participatory management emphasizes the ideas of employees at all levels and encourages them to contribute.

Leaders who act in direct patient care act safely because they feel supported by the clear position and support received from managers, regardless of the shift in which they work. Management that values people's understanding and the recognition of the importance of interpersonal relationships at work, uses this tool to qualify nursing practice and achieves satisfactory results in the quality of care..$^{15}$

Hospital management is seen as a reference and allied in patient care, with active participation in problem solving. The implementation of a safety culture, permeates multiple instances of an institution and requires involvement and commitment from the central administration to support services..$^{14}$

Participants listed the protocols as an aid in developing a safe culture. Because they promote the dynamism between management design, guided by rational tools, formalized rules and well-defined tools that systematize health care activities, which enables the process of change through care practices. ${ }^{17}$
The processes of change are complex, especially in the sphere of care management, the standardization and control processes and the involvement with individuals from different groups who seek inter-subjective meanings, build meanings for their practices. ${ }^{17}$ Doctors new to the institution are faced with a consolidated safety culture and are invited to be part of this new concept of care.

Protocols are allied in the standardization of patient services, speed up care, but a constant review and update is necessary, as the demand of service and regulatory agencies of safe practices. They still serve as a barrier to prevent AEs; however, only when the service is performed, it is perceived the gaps in the protocol. So, there is a need to stop, evaluate, review the proposed model and restructure it, to facilitate the work without compromising PS, as they guide and facilitate the performance of the procedures as well as contribute to the communication.

Professionals understand that there are motivating elements for the construction of work, which reflect on job satisfaction, such as opportunities in the institution and salary compensation, cited by some leaders who had the opportunity to change positions. Professionals in another study expressed a sense of pride in working at an accredited health institution for the benefits it offers, such as professional growth. ${ }^{11}$

The salary issue has been addressed as there are no late payments and the atmosphere is financially stable in the institution. The study in Minas Gerais, in an accredited institution of excellence, proved that in addition to safe care, accreditation is important for the survival of the institution. ${ }^{27}$ In this sense, in people management, recognition is a key element of the relationship of the individual with work and organization. ${ }^{28}$

The working conditions were mentioned by the participants of the FG, as they followed the evolution of the institution and consequent adequacy of the physical structure. Inadequate physical space for care activities causes discontent and psychological distress in workers, leaves them vulnerable to work-related accidents and alters the work process. ${ }^{29}$

In this sense, the model of an organization that contemplates the specificity of health work and considers the subjectivity of workers, which enables pleasurable work on a larger scale than suffering, builds a positive individual and collective identity, which it possible to provide safe and excellent care. ${ }^{29}$ The certification guaranteed improvements in the physical environment, brought more comfort and safety for professionals, who feel the results of collective work and the satisfaction of performing daily work with favorable conditions.

Professional achievement is evident in the factors addressed and reports suggest that professionals are driven by stimulus and not just by demands. These aspects have contributed to the change in culture and portray a management that relies on individual potential for the benefit of the community. 
Accreditation has provided a process that represents an important capacity building strategy within the institution, as it is a permanent qualification proposal that provides the guarantee of safe and quality care.

\section{FINAL CONSIDERATIONS AND IMPLICATIONS FOR PRACTICE}

This research showed that the contributing factors for a positive PS culture were teamwork, professional appreciation, management support, protocol implementation, job satisfaction and working conditions. Factors identified by the convergence group and adopted by hospital managers, which enabled processes and results that motivate workers to take on significant roles in the advancement of PS, assimilating and taking responsibility for changes.

The assessment of cultural changes through research and the recognition of the importance of results by managers, denote the priority to keep actions focused on safe culture, based on reliable and updated results. Contributing factors constitute themselves in action indicators to preserve and enhance the resilience of participants. The gradual dissemination of the identified factors among the protagonists of the process has the potential to strengthen the team and ensure the development of safe care, i.e., the evidences of the present study support the initiatives aimed at consolidating safe care, with a multi-professional view. Addressing the discussion about the PS culture should be a strategy implemented by institutions and their managers, establishing it as guidelines.

Also, it is important for managers to encourage and strengthen teamwork, as this is an essential element in order to obtain a culture of positive safety and safe assistance. It is also important to emphasize the need to address this aspect in academic education.

\section{FINANCIAL SUPPORT}

Institutional Program for Scientific Initiation Scholarships (Programa Institucional de Bolsas de Iniciação Científica, PIBIC), National Council for Scientific and Technological Development. Two undergraduate scholarships awarded to the undergraduate students: Catiele Raquel Schmidt and Karina Andressa Cavalheiro.

\section{REFERENCES}

1. Institute of Medicine (US). Committee on Quality of Health Care in America. To Err Is Human: Building a Safer Health System. Institute of Medicine. Copyright. Washington (DC): The National Academies Press; 2000.

2. World Health Organization (WHO). World Alliance for Patient Safety: forward programme. Geneva: WHO; 2004

3. World Health Organization (WHO). World Alliance for Patient Safety. Global Patient Safety Challenge: 2005-2006. Geneva: WHO; 2005.
4. Caldana G, Guirardello EB, Urbanetto JS, Peterlini MAS, Gabriel CS Rede Brasileira de Enfermagem e Segurança do Paciente: Desafios e Perspectivas. Texto Contexto - Enferm. 2015 sep;24(3):906-11

5. Rede Brasileira de Enfermagem e Segurança do Paciente REBRAENSP Estratégias para a segurança do paciente: manual para profissionais da saúde. Porto Alegre: EDIPUCRS; 2013. p.1-132.

6. Ministério da Saúde (BR). Portaria n. 529, de 10 de Abril de 2013. Institui o Programa Nacional de Segurança do Paciente (PNSP). Diário Oficial da União, Brasília (DF), 1ํo abr 2013; Seção 1: 1-4.

7. Ministério da Saúde (BR). Agência Nacional de Vigilância Sanitária. Resolução de Diretoria Colegiada (RDC) n. 36, de 25 de julho de 2013. Institui ações para a segurança do paciente em serviços de saúde e dá outras providências [Internet]. Brasília (DF): Ministério da Saúde 25 jul 2013. Available from: http://bvsms.saude.gov.br/bvs/saudelegis/ anvisa/2013/rdc36_27_07_2013.htm

8. Romero MP, González RB, Calvo MSR, Fachado AA. A segurança do paciente, qualidade do atendimento e ética dos sistemas de saúde. Rev Bioét. 2018 dec;26(3):333-42.

9. Ministério da Saúde (BR), Agência Nacional de Vigilância Sanitária Implantação do Núcleo de Segurança do Paciente em Serviços de Saúde Caderno $n^{\circ} 6$ da Série: Segurança do Paciente e Qualidade em Serviços de Saúde [Internet]. Brasília: ANVISA;2016; [cited 2019 05 01]. Available from: https://www20.anvisa.gov.br/segurancadopaciente/index.php/publicacoes/ item/caderno-6-implantacao-do-nucleo-de-seguranca-do-paciente

10. Maia CS, Freitas DRC, Gallo LG, Araújo WN. Registry of adverse events related to health care that results in deaths in Brazil, 2014-2016. Epidemiol Serv Saúde. 2018 jun;27(2):e2017320.

11. Camillo NRS, Oliveira JLC, Bellucci Junior JA, Cervilheri AH, Haddad MCFL, Matsuda LM. Acreditação em hospital público: percepções da equipe multiprofissional. Rev Bras Enferm. 2016 may/jun;69(3):451-9.

12. Carvalho REFL, Cassiani SHDB. Cross-cultural adaptation of the Safety Attitudes Questionnaire - Short Form 2006 for Brazil. Rev Latino-Am Enfermagem. 2012 jun;20(3):575-82.

13. Minayo MCS. O desafio do conhecimento: pesquisa qualitativa em saúde. 14ª ed. São Paulo: Hucitec; 2014.

14. Wegner W, Silva SC, Kantorski KJC, Predebon CM, Sanches MO, Pedro ENR. Education for culture of patient safety: Implications to professiona training. Esc Anna Nery. 2016;20(3):e2016--68.

15. Chaves LDP, Mininel VA, Silva JAM, Alves LR, Silva MF, Camelo SHH Supervisão de enfermagem para integralidade do cuidado. Rev Bras Enferm. 2017 oct;70(5):1165-70.

16. Paixão TCR, Balsanelli AP, Bohomol E, Neves VR. Competências gerenciais relacionadas à segurança do paciente: uma revisão integrativa. Rev SOBECC. 2017 oct/dec;22(4):245-53.

17. Azevedo CS, Sá MC, Cunha M, Matta GC, Miranda L, Grabois V. Rationalization and sensemaking in care management: an experience of change in a hospital of the SUS (Unified Health System). Ciên Saúde Colet. 2017;22(6):1991-2002

18. Altin SV, Tebest R, Kautz-Freimuth S, Redaelli M, Stock S. Barriers in the implementation of interprofessional continuing education programs - a qualitative study from Germany. BMC Med Educ. 2014;14(227):1-9.

19. Rodrigues CCFM, Santos VEP, Sousa P. Patient safety and nursing: interface with stress and Burnout Syndrome. Rev Bras Enferm. 2017 sep/oct;70(5):1083-8.

20. Farias ES, Santos JO, Góis RMO. Comunicação efetiva: elo na segurança. Ciênc Biológicas Saúde Unit. 2018;4(3):139-54.

21. Macedo TR, Rocha PK, Tomazoni A, Souza S, Anders JC, Davis K. Cultura de Segurança do Paciente na perspectiva da equipe de enfermagem de emergências pediátricas. Rev Esc Enferm USP. 2016 sep/oct;50(5):757-63.

22. Oliveira JLC, Silva SV, Santos PR, Matsuda LM, Tonini NS, Nicola AL. Segurança do paciente: conhecimento entre residentes multiprofissionais. Einstein (SP). 2017 mar;15(1):50-7. 


\section{Patient safety culture}

Heidmann A, Trindade LF, Schmidt CR, Loro MM, Fontana RT, Kolankiewicz ACB

23. Minayo MCS. Valorização profissional sob a perspectiva dos policiais do Estado do Rio de Janeiro Professional. Ciênc Saúde Coletiva 2013;18(3):611-20.

24. Wegner RS, Godoy LP, Godoy TP, Bueno WP, Pereira MS. Trabalho em equipe sob a ótica da percepção dos gestores e funcionários de uma empresa de serviços. Rev Pretexto. 2018;19(1):11-24.

25. Costa DB, Ramos D, Gabriel CS, Bernardes A. Cultura de Segurança do Paciente: Avaliação pelos profissionais de enfermagem. Texto Contexto - Enferm. 2018;27(3):1-9.

26. National Patient Safety Foundation (NPSF). Livres de danos Acelerar a melhoria da segurança do paciente quinze anos depois de To Err Is Human. Boston: NPSF; 2015.
27. Siman AG, Cunha SGS, Amaro MOF, Brito MJM. Implicações da acreditação para a gestão do serviço hospitalar. Rev Enferm do CentroOeste Min. 2017;7:1-10.

28. Duarte MLC, Boeck JN. O trabalho em equipe na enfermagem e os limites e possibilidades da Estratégia Saúde da Família. Trab Educ Saúde. 2015;13(3):709-20.

29. Souza NVDO, Gonçalves FGA, Pires AS, David HMSL. Neoliberalist influences on nursing hospital work process and organization. Rev Bras Enferm. 2017;70(5):912-9. 